\title{
My Gentleman of the White Knights
}

\author{
Clea H. Notar
}

\begin{abstract}
Pourquoi refuser de traduire? Pourquoi rejeter l'acte de traduction? Dans l'histoire fictive qui nous concerne, ce refus est, au fond, un retour aux racines culturelles, linguistiques, géographiques et physiologiques de la personne qui écrit. Dans cettelettreà sonfrère parisien, elle se rend compte qu'elle ne maîtrisera jamais l'art de se traduire dans une autre langue. Ainsi, elle avoue avoir étéséduite par le mystère de la différence: une langue étrangère, une culture exotique, un pays lointain, le savoir faire d'un individu plus expérimenté, le territoire inconnu du corps de l'autre.
\end{abstract}

My dearest brother:

It has taken me a long while to write to you. It seems that the more time I spend here, the farther away I move from understanding you and understanding the country in which you grew up and lived for so many years.

I'm afraid my visits to Paris did not help. I thought, perhaps, it would bring me closer to you.

Jean, I beg of you to read this believing how much your sister loves you. I've been thinking a lot, trying to sort things out for myself. But I swear to you, I've never forgotten the time we spent together, the night we stayed awake until dawn, falling asleep on the living room carpet, your arm beneath my head, my body curled up against your side. I haven't forgotten how naturally our bodies seemed to fit together.

Weare like two halves of a whole, you and I.

I suppose I feel I should apologize for writing in English. It is my language, you know, the only one I have in which to express myself. It often fails me and I feel its inadequacies most at these times when I think of what I want so much to share with you.

I have been trying to learn French, in order that I might write to you 
in your mother tongue. To me it's a beautiful language, as beautiful and unattainable as you, who often seem so unreachably far away.

That I haven't written of late does not mean that I haven't been thinking of you. In fact, I keep a picture of you in my mind. It's a picture of your whitearms, of your back. You have taken off your shirt and are hanging it over my bare window. It is dawn. We're tired and the bluish light of morning threatens the dull gray of my room; a sleepy end to another one of our late nights. Une nuit blanche, c'est comme ça qu' on l'appelle, n'est ce pas?

It's winter and the climate here is terrible. My body rebels against the cold. As though disguised, I protect myself in layers of clothing. At first the winds and snow made me hate what little I had to offer as a defense, the necessity of this act. Now, it's my flesh that longs to expose itself to more compassionate air, that has learned to hate these batterers.

Please, don't let this expression of emotion scare you. In general, I am comfortable and happy here. This country is certainly a funny one. It's not at all like yours. I know this is a simple statement but, at times, it's easy for me to forget the distance between us, the difference in the lives we live, the cities in which we move, the lands which house us.

Jean, you would not believe how much open space exists here. This is a country in which one could lose oneself. But more often I discover it as a place in which I am free to explore, to roam, to walk stomping through the streets, turning back to smile at my footsteps in the snow. In your country I felt most my obligation to the crowd; not to jostle the bodies. And if I dared or if I panicked from a feeling of claustrophobia, and ran in another direction, how quickly their fingers would zero in on me, a target, a foreigner.

I think now of how difficult it must have been for you because no one would suspect from looking at you that you were anything but another face and body amongst many. And when you dared to speak up, to speak out, they were shocked. Yours was an affront that seared with deception. As for me, I could never disguise my body enough to allow myself to pass for one of them. Knowing me to be a foreigner, it comes as no surprise, almost with expectation, that my voicestraining to speak the language only reveals my accent, my real identity.

Do you understand what I'm saying? I hate these letters. When we're together I feel that we can lie for hours, my arm lazily draped across your chest, my stockinged feet tucked for warmth between 
yours. There is our true communication. When we sit facing each other, our open legs intertwined, knees bent, like friendly grasshoppers, you run your hands through my hair. (It is short again. As short as yours.) Your eyes follow your fingers as they move from my crown and down through the thick, dark blondness to the back of my neck.

We can speak like that, silently, for hours. Ne pense jamais, jamais que je ne suis pas restée attachée, à t'aimer.

I had a dream of the two of us. This wasn't long ago. It was night in the dream, two or three in the morning, and yet there was bright sunlight streaming through a small window high on the wall above our heads. We were sitting cross-legged in the cramped hallway outside of my flat. I could feel you. Both our eyes were closed but I could feel a thick cloud of your senses. We were kissing gently. Suddenly, you bit down on your lip. (It could have been mine.) There was no pain, simply a sensation that something had burst. When, in the dream, I opened my eyes, I saw through the yellow light, your face covered in blood. Your eyes were closed so as to prevent the blood from dripping into them. Your mouth was closed, too. I guess that's where the blood had come from. The white walls of the corridor were splattered with red.

My brother, I have to say what I fear saying most, since I know that these words do nothing to change the truth of our flesh: there's blood between us. I feel it in my body. I cannot reject this.

But I was unhappy in your country. I was happy to be beside you but unhappy at feeling the gaze of others, that which surrounded us. I'm frightened by the look which insists that we are guilty. We are guilty because we appear in public together, in disregard of the rules established to prevent us from acting through our bodies. They want us to explain and I cannot. I' $m$ too exhausted from wrestling with the language of your countrymen to defend myself. And you, if you remain silent, you will escape interrogation. They will let you go. But my appearance, my presence, condemns me the very moment I step onto the streets of your city. Comment établir l'innocence de mon corps dans ce monde?

It's easier for me here, with you apart from me, to understand our situation, as well as my own. Jean, I don't want to make you feel ill at ease. Tu es vraiment un paradoxe, toi, qui peut si facilement gêner les autres mais qui est d'un côté si vulnérable, si facilement gêné. 
I am not accusing you - if I am, it's only through loving you that I do so. It's simply that when we're together, like that night I took you walking in my neighbourhood: we stopped at a small bar that was open late. You ordered a beer. We sat in the stuffy warmth, in the back, at a small round table. It was dark and crowded. I can't remember what we were speaking about but we were laughing. I felt flushed from our laughter. I was telling you a story when you leaned over and kissed the side of my neck. It confused meand I faltered, lost my place in the words, but I continued. When we left, walking briskly together through the street, I kept my gloved hands in my pockets, my shoulders hunched, my chin down. We walked home in silence.

I used to dream that one day I'd be able to speak your language as well as you do. Then I began to feel frustrated, realizing that to try only caused me to become conscious of how trapped I was by words that will never belong to me. So why do I bother to write to you, even so infrequently? Because you are not here. And because these words, in my language, in yours, are the pitiful substitute I have for touching your body.

Jean, what is the bond between us? How can you be so different from me, with such a different experience of life, lived through your body, speaking your language, and still I feel as though you are me?

It must be our childhood. Our youth persists in our bodies and that's why the others do not understand, why I will not touch you when we walk outside together. Because, at the sight of us, if my arm hung comfortably around your neck and if your arm held my waist against your side, they would speak theone word they keep to beused for us, that word that both repudiates our childhood and damns us for its existence.

Safe inside, yourskin is cool, white-pink, gentle. Where is myleg? It has disappeared between your thighs. Where is your arm? It has become part of my back. Where is your shoulder, my head? Together, Jean, we become one body, one nest of skin and flesh and muscle and hair.

Then, quietly you speak. I hesitate. I want to speak, too, but when I try I only see us the way they must. I cannot use the words the way you can, the way you do, not thinking as you speak of the possibility that you are confusing the order, an order designed for those born knowing your language. It is with this that I struggle. Et c'est à ce moment que je me sens comme une prisonnière avec ta langue dans ma bouche. 
So I have decided that I can't write to you anymore. There must only be silence between us. And the harmony that exists in the conversations between our bodies, that, I suppose, will continue if we' re ever together again.

This is very difficult. I feel the pain of separation, the physical anguish of you being cut away from my body. But then, we've been separated forever, from the moment of birth we were placed in two different countries, taught to speak different languages, living two different lives.

I'm here despite any real choice in this matter and I choose to remain here. So it's silly of me to continue longing for your company. And it is time for me to acknowledge my roots in this country; a country young in documented history and old in unwritten mythology; a land with a great deal of space. It is here that I must establish myself, where I have to allow my body to breathe freely, to feel the white expanse of this country, away from the social tradition which binds us, all the while preventing us from ever being together, completely.

My brother,Iadmire you so much. I admire how you havesurvived in that gray city, I admire your grace and the purity of your physical honesty: your brazenness. But something that has grown inside me separates me from you, prevents me from knowing you the way I once thought I did.

It is our difference which divides us. I know you'll understand this. As for me, I've just begun to see that we cannot be together. I muststay here.

I want to tell you something. I've met a woman. Her name is Margaret. Some people say we look alike. In a sense, I guess this is true. I feel very close to her and if you ever decide to visit here I'd like very much for the two of you to meet.

Tu sais, je pense toujours à toi, Jean. You are my brother and nothing can change that.

Darling, I leave you with your own words, translated. Please, excuse my English.

'I only wish I could have you in my arms so I could hold you and squeeze you tight. Remember the things we used to do together. Try to recognize the dotted lines. And kiss it. A thousand big kisses, sweetheart, from ...'

yoursister.

Montréal 1987 